\title{
International Banking and Cross-Border Effects of Regulation: Lessons from Germany*
}

\author{
Jana Ohls, ${ }^{a}$ Marcus Pramor, ${ }^{\mathrm{a}}$ and Lena Tonzer ${ }^{\mathrm{b}}$ \\ ${ }^{a}$ Deutsche Bundesbank \\ ${ }^{\mathrm{b}}$ Halle Institute for Economic Research
}

\begin{abstract}
We analyze the inward and outward transmission of regulatory changes through German banks' (international) loan portfolio. Overall, our results provide evidence for international spillovers of prudential instruments. These spillovers are, however, quite heterogeneous between types of banks and can only be observed for some instruments. For instance, domestic affiliates of foreign-owned global banks reduce their loan growth to the German economy in response to a tightening of sector-specific capital buffers, local reserve requirements, and loan-to-value ratios in their home country. Furthermore, from the point of view of foreign countries, tightening reserve requirements is effective in reducing lending inflows from German banks. Finally, we find that business and financial cycles matter for lending decisions.
\end{abstract}

JEL Codes: F30, G01, G21, G28.

*This paper was written as part of the International Banking Research Network (IBRN) project on cross-border regulatory spillovers. We thank Deutsche Bundesbank, the IBRN, and the Bank for International Settlements for providing data. Also, we would like to thank Claudia Buch, Luisa Carpinelli, Evren Damar, Elisabetta Fiorentino, Linda Goldberg, Friederike Güttner, Chris Jürschik, Cornelia Kerl, Axel Loeffler, and Adi Mordel as well as seminar participants at the Deutsche Bundesbank for their helpful comments. All remaining errors and inconsistencies are entirely our own responsibility. The paper represents the authors' personal opinions and does not necessarily reflect the views of the Deutsche Bundesbank or its staff. Author contact: Jana Ohls, Deutsche Bundesbank, Wilhelm-Epstein-Strasse 14, 60431 Frankfurt am Main, Germany, jana.ohls@bundesbank.de; Marcus Pramor, Deutsche Bundesbank, Wilhelm-Epstein-Strasse 14, 60431 Frankfurt am Main, Germany, marcus.pramor@bundesbank.de; Lena Tonzer, Halle Institute for Economic Research (IWH), Kleine Maerkerstrasse 8, 06108 Halle (Saale), Germany, lena.tonzer@iwh-halle.de. 


\section{Introduction}

In response to the recent financial crisis, numerous and substantial changes have been made to the architecture of the financial system. One key objective is to maintain financial stability by widening the focus of regulation from individual banks to the stability of the financial system as a whole. Prudential instruments can help in achieving this objective. The effectiveness of these instruments for financial stability hinges, however, on the absence of unintended leakages and spillovers. In integrated financial markets, such as in the German case, this might be a challenge given that banks can circumvent prudential regulation by adapting their global activities.

In this paper, we analyze how prudential policies implemented in domestic and foreign markets affect German banks' local and global lending behavior following the methodology described in Buch and Goldberg (2017). Our study relates to the current policy debate on cross-border effects of regulatory policies and reciprocation. For instance, the European Systemic Risk Board (ESRB), which is the European macroprudential authority, has recently issued recommendations calling for an annual assessment of cross-border effects of national macroprudential measures (ESRB 2015). We use detailed micro-level data on German banks to study regulatory spillovers across borders in three different dimensions: inward transmission of foreign regulation into Germany due to international activities of German global banks, inward transmission through domestic affiliates of foreign-owned global banks, and outward transmission to foreign countries through foreign lending of German global banks and their foreign affiliates 1

The German case in the International Banking Research Network (IBRN) is interesting because of the high degree of international activity of German banks. We analyze international lending growth of German-owned banks to fifty-two foreign countries. These foreign claims amount to 33 percent of total claims of German banks. Also, Germany hosts seventy-two affiliates of foreign global banks which hold 9 percent of all German claims. From a German policy

\footnotetext{
${ }^{1}$ Please see Buch and Goldberg (2017, figure 1) for a detailed presentation of the terminology used to describe inward and outward transmission.
} 
perspective, it is important to understand whether and how these foreign-owned banks transmit regulatory changes from their home country into the German market. Finally, German banks enter foreign markets not only through cross-border lending but also through foreign branches and foreign subsidiaries. Besides following the common IBRN methodology, our data allow us to test whether foreign branches and subsidiaries behave differently in response to changes in regulation.

While our results provide evidence for international spillovers of changes in prudential instruments, we document that these spillovers are heterogeneous between types of instruments and types of banks. First, analyzing the inward transmission of regulatory changes abroad due to foreign exposures of German banks, we find that, for the average bank, domestic lending growth increases when foreign regulation tightens. This holds true specifically for a tightening in capital requirements and loan-to-value ratios.

Second, domestic affiliates owned by foreign global banks contract their lending growth in Germany in response to a policy tightening in their home country. This finding is surprising, as one might expect foreign global banks to respond to stricter regulation in their home country by increasing lending activities by their domestic affiliates located in Germany that are not subject to that regulation. However, regulatory pressure can have indirect effects on domestic affiliates owned by foreign global banks if a parent bank draws resources from these affiliates in order to fulfill tighter requirements in the home country. While there is substantial heterogeneity between different types of banks, the role of bank characteristics differs across regulatory instruments. Overall, the retrenchment from lending in Germany is less pronounced for larger banks that are better capitalized and that display a higher ratio of illiquid assets to total assets.

Third, for the outward transmission exercise, we find evidence that international lending growth by German global banks is negatively affected by stricter regulation in the destination country. However, for most prudential instruments, we only find short-run effects that vanish after one quarter. Only in the case of local reserve requirements do we find that a tightening in this instrument significantly reduces loan growth over a longer time horizon. This suggests that reserve requirements, which have been used mainly by 
emerging markets in our sample, have been successful in controlling capital inflows from German global banks.

Furthermore, we study whether foreign branches and subsidiaries of German global banks differ in their responses to changes in prudential regulation in their foreign host country. Institution-based regulation in the foreign host country usually applies to foreign subsidiaries, while foreign branches are subject to home, in this case German, regulation. The differential treatment of branches and subsidiaries may facilitate regulatory leakages in the foreign country. Our results suggest that foreign subsidiaries are constrained by foreign regulation, as they reduce lending growth in response to a tightening in the foreign country prudential index (as well as in sector-specific capital buffers, loan-to-value ratios, and foreign reserve requirements). Foreign branches, however, do not change their lending growth significantly following a change in foreign regulation (except for a negative effect of concentration ratios and a positive contemporaneous effect of the prudential index). In contrast to foreign subsidiaries, marginal effects of a tightening in prudential instruments are positive in the foreign branch subsample but not significant.

Finally, we find that business and financial cycles affect lending decisions. For instance, domestic affiliates of foreign global banks increase lending growth when the financial cycle in their home country expands. Similarly, German global banks raise lending growth to destination countries that experience an upturn in their financial and business cycles. This procyclical connection with destinationcountry cycles, however, cannot be found for loan growth by German banks' foreign affiliates hosted in these countries.

Our study adds to research on the pattern of German banks' international activities and cross-border spillovers. Buch, Koch, and Koetter (2014), for example, find that more productive German banks are more likely to maintain cross-border activities. In contrast, the propensity to maintain cross-border loans decreases with risk aversion (Düwel, Frey, and Lipponer 2011). Besides productivity and risk aversion, bank size also matters. While a large percentage of German banks are active abroad, only large banks maintain foreign affiliates (Buch, Koch, and Koetter 2011b). We include a set of bank control variables based on this literature. 
The recent financial crisis has shifted banks' international activities. Banks have withdrawn from international markets, with one reason being changes in funding conditions or government interventions (Buch, Neugebauer, and Schröder 2013; Kerl and Koch 2015). Internal capital markets have been used to stabilize foreign affiliates' lending activities after the crisis depending on parent banks' characteristics (Frey and Kerl 2015). Investigating international spillovers, Buch, Koch, and Koetter (2011a) look at the effect of rescue measures implemented in response to the recent financial crisis in the United States and Germany and find evidence of spillover effects through foreign affiliates.

Our paper adds to the aforementioned literature by focusing on the effects of changes in prudential regulation on German banks' (international) lending activity. We address this issue by exploiting a novel data set on regulatory changes obtained from Cerutti et al. (2017), thereby contributing to a relatively new strand of the literature (e.g., Aiyar, Calomiris, and Wieladek 2014; Claessens, Ghosh, and Mihet 2013; and Jiménez et al. 2012). Overall, we find a withdrawal from foreign markets when regulation in the home or foreign market tightens.

The paper is structured as follows. The following section describes the data and stylized facts on international activities of German banks. The third section presents regression results for the analysis of inward and outward transmission of changes in prudential instruments. In addition to the common methodology, we analyze whether adjustments differ for foreign branches and subsidiaries of German banks. The final section concludes the paper.

\section{Data and Stylized Facts for Germany}

\subsection{Bank-Level Data}

We use confidential data collected by Deutsche Bundesbank for the monthly balance sheet statistics of banks (BISTA) The sample covers the period from 2002:Q1 to 2013:Q4. Data are available

\footnotetext{
${ }^{2}$ For more information on Deutsche Bundesbank's monthly balance sheet statistics of banks, see https://www.bundesbank.de/Redaktion/EN/ Standardartikel/Service/Reporting_systems/monthly_balance_sheet_statistics. html?https=1.
} 
for (i) all banks located in Germany, including domestic affiliates owned by foreign global banks, and (ii) German banks' branches and subsidiaries operating abroad. Data on German banks' international activities by destination country are obtained from Deutsche Bundesbank's external position report 3 The analysis is conducted at a quarterly frequency. To aggregate monthly data to quarterly frequency, we use quarter-end values.

\subsubsection{Dependent Variables}

For the dependent variable, we use log changes in loans. In the baseline specification, we employ total loans; for robustness tests, we exploit the sectoral breakdown and analyze the effect on loans to banks, non-financial firms, and the public sector separately 4

For the inward transmission exercise, we resort to total domestic loans as provided by the monthly balance sheet statistics. These data are available for domestic (German) banks and domestic affiliates of foreign global banks 5 For the latter, we can identify the home country of the foreign parent bank. For the outward transmission exercise, we make use of data from the external position report. All German banks, including their foreign affiliates (branches and subsidiaries), are required to report foreign asset positions, broken down by destination country. While foreign subsidiaries of German banks have to report their foreign claims individually, foreign branches are aggregated for each German parent bank by country 6 Our analysis includes the fifty-two largest destination countries (in terms of overall claims in the German banking system) and the ninety-two

\footnotetext{
${ }^{3}$ Deutsche Bundesbank's data on the external positions of individual German banks are confidential but can be used under certain conditions for research projects. For more information, please see http://www.bundesbank.de/ Navigation/EN/Bundesbank/Research/RDSC/rdsc.html.

${ }^{4}$ For a more detailed discussion of the sectoral breakdown and the resulting effects, we refer the reader to Ohls, Pramor, and Tonzer (2016).

${ }^{5}$ Please note that domestic affiliates owned by foreign global banks are not included in the outward transmission exercise due to data restrictions. In the inward transmission exercise, these banks are only included when specifically analyzing inward transmission through domestic affiliates of foreign global banks. We cannot differentiate between branches and subsidiaries due to data limitations.

${ }^{6}$ For a comprehensive description of the external position report, see Fiorentino, Koch, and Rudek (2010).
} 
largest banks (plus their foreign affiliates) in terms of foreign assets. We thereby cover more than 90 percent of the German banking system's total foreign loans as of December 2013. Our analysis focuses on the intensive margin, i.e., on lending growth, not on adjustments along the extensive margin. In order to reduce the cases of entries into and exits out of foreign markets in our data set, we exclude small banks and less relevant destination countries. As a result, 84 percent of all bank/destination country combinations show up in at least 75 percent of all sample periods.

Regarding the level of consolidation, we proceed as follows. When studying the lending responses of German-owned banks, we use consolidated (parent plus foreign branch) data if a German global bank owns foreign affiliates, but also include banks that lend directly cross-border without owning a foreign affiliate. This is the case for inward transmission through international activities of German global banks and the outward transmission exercise. This consolidation choice accounts for the fact that parents and their foreign branches are often subject to home-country regulation, whereas subsidiaries are subject to foreign-country regulation. We approximate consolidated exposures at the parent-foreign branch level by using the unconsolidated positions of the parent and its foreign branches and a proxy for intrabank flows. This proxy has been used in previous studies based on these data (Frey and Kerl 2015). For the inward transmission specification through domestic affiliates of foreign global banks, we use unconsolidated data due to data constraints, but control for internal capital market positions.

To account for outliers, we drop observations for which the log change of lending exceeds 100 percent in absolute terms. We only keep series for which at least two consecutive observations and at least eight observations in total are available. Qualitatively, our main regression results are not affected by the sample adjustment. Summary statistics are provided in table 1.

\subsubsection{Balance Sheet Characteristics}

The balance sheet characteristics are taken from the monthly balance sheet statistics (BISTA). To remove outliers, we drop observations for which the ratios described below are less than zero 


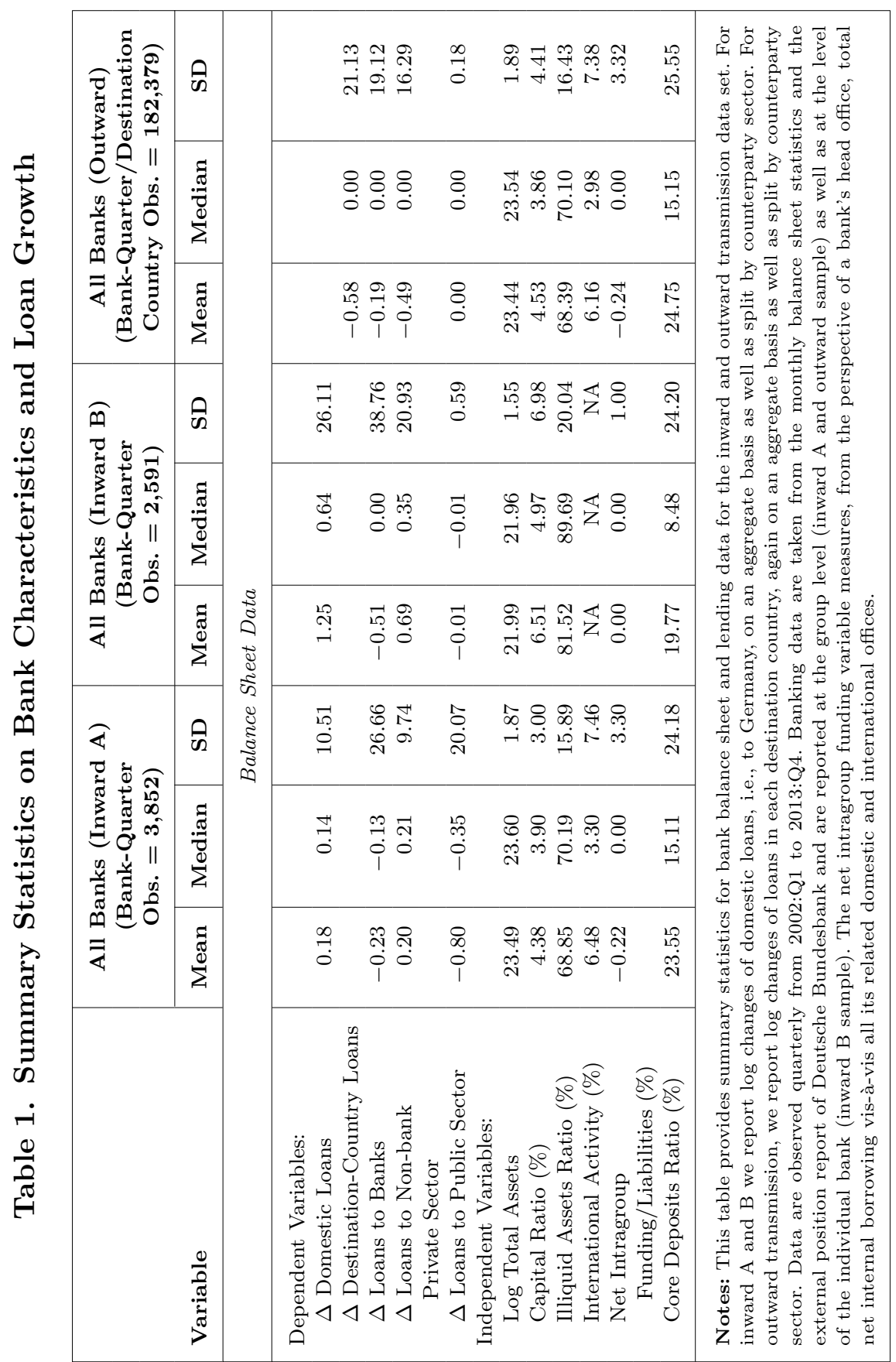


or greater than 100 percent 7 Balance sheet variables include the illiquid assets ratio, the core deposits ratio, the capital ratio, the net intragroup funding ratio, the log of total assets, and the international activities ratio. These variables are defined in table 8 in the appendix, with corresponding summary statistics provided in table 1.

\subsection{Data on Prudential Instruments}

To analyze spillovers of regulatory policies, this study draws on the IBRN Prudential Instruments Database described in Cerutti et al. (2017), which provides quarterly information on changes in seven prudential instruments plus a composite index for more than sixty countries over the 2000-14 period. The prudential variables provide information on tightening (coded by 1) and loosening (coded by -1 ) of a specific instrument in the specific quarter when the change came into effect, and zero otherwise. In this study, we focus on six out of seven instruments to study spillovers of prudential policies: general capital requirements, sector-specific capital requirements, loan-to-value ratio limits, reserve requirements (in local and foreign currency), and concentration limits. We exclude interbank exposure limits from our analysis due to the small number of changes for this instrument in our sample (see table 2).

We use this information in our analysis to control for individual changes in prudential instruments in the home country of domestic affiliates of global foreign banks and in the destination country of lending by German banks. We do not analyze the effects of regulatory changes in Germany on bank lending because we do not observe enough changes in regulatory instruments in Germany over the sample period. Instead, we control for German regulation through time fixed effects. See Buch and Goldberg (2017) for more details on the construction of regulatory measures. The variables are defined as follows:

\footnotetext{
${ }^{7}$ The variable capturing internal capital market positions can also be less than zero; we therefore drop values that exceed 100 percent in absolute terms.
} 
March 2017

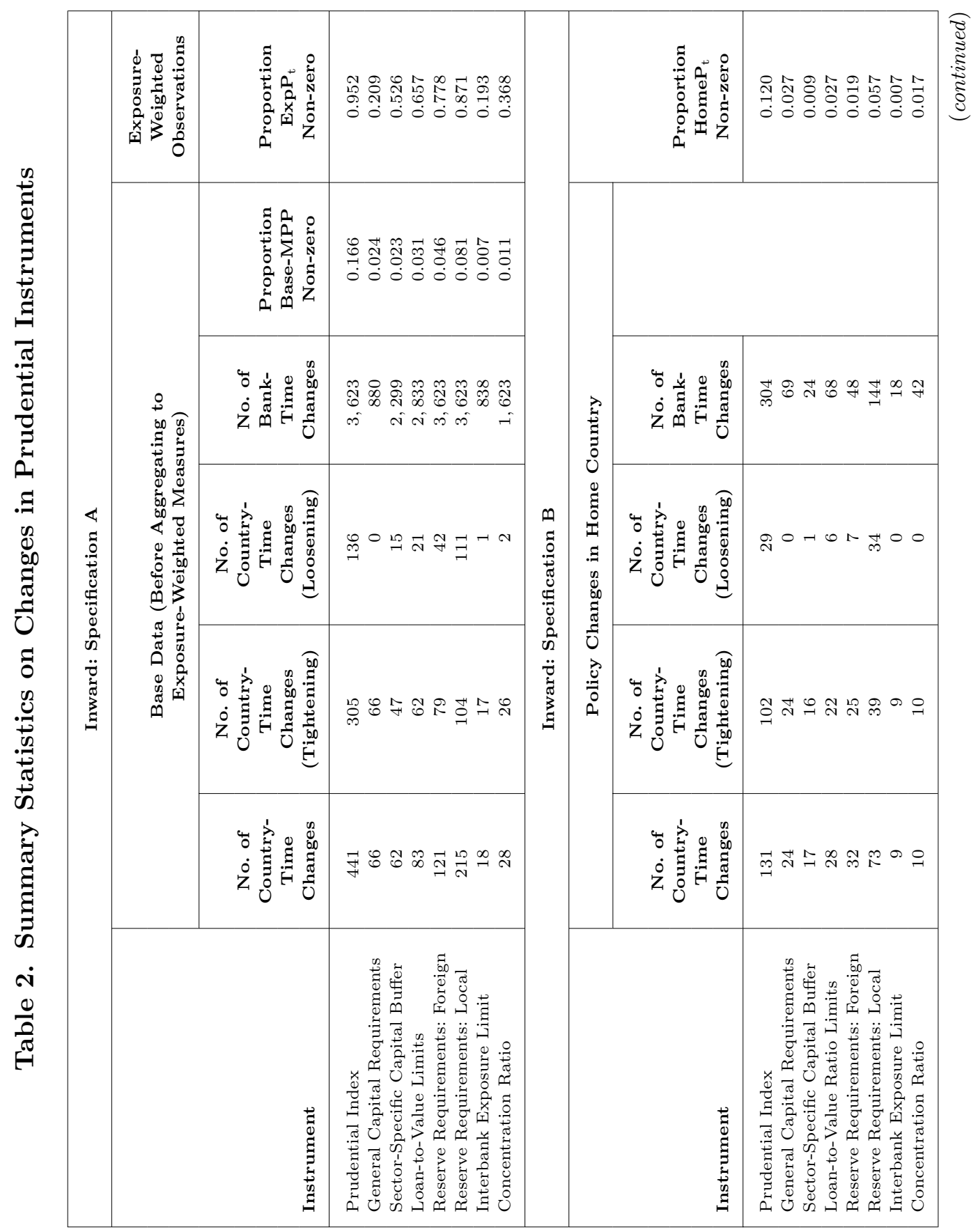




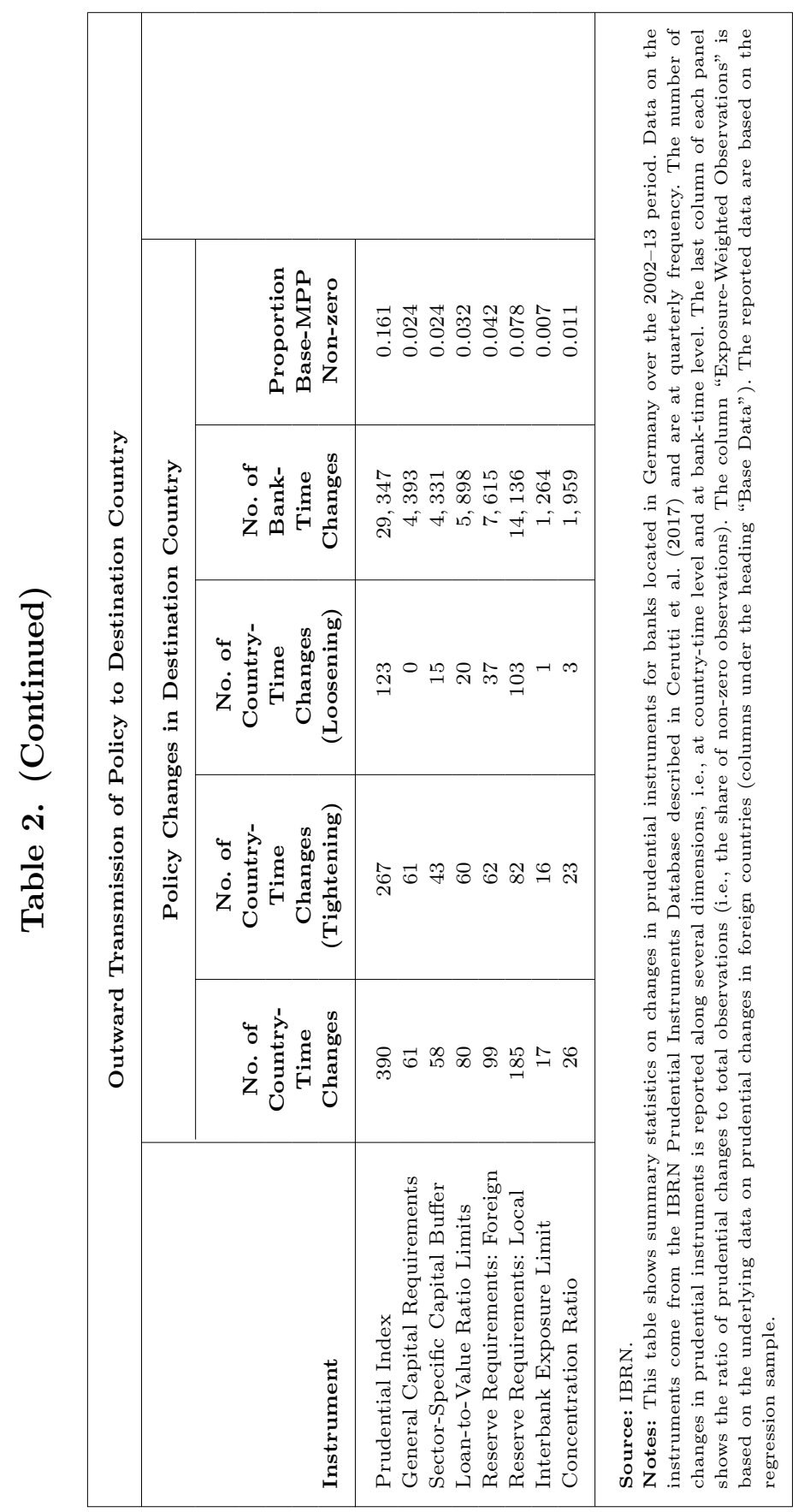


- Regulation weighted by foreign exposures (all exposures of banks outside the home country): $\operatorname{Exp}_{b, t-l}$ (where $l=0,1$, 2 ) = foreign-exposure-weighted regulation

- Home-country regulation (home country $=$ country of the foreign parent bank): HomeP ${ }_{j, t-l}$ (where $\left.l=0,1,2\right)=$ homecountry regulation with zero, one, and two lags

- Destination-country regulation (destination country $=$ country to which the loan goes): Dest $P_{j, t-l}($ where $l=0,1,2)=$ destination-country regulation with zero, one, and two lags

Table 2 provides summary statistics for changes in these instruments. We see that most changes occur for reserve requirements on local- and foreign-currency deposits followed by capital requirements. A tightening of standards occurred more often than a loosening.

Our sample is rather dominated by advanced economies (60 percent of the underlying observations in the inward A and outward specifications, 90 percent of the underlying observations in the inward B specification). However, we observe relatively more regulatory changes in emerging market economies for the significant regulatory instruments. This holds particularly true for foreign and local reserve requirements.

\subsection{Data on the Business and Financial Cycles}

The second database focuses on macroeconomic conditions and was provided by the Bank for International Settlements (BIS). It allows us to control for the current state of the business (output gap) and financial (credit-to-GDP gap) cycles when assessing regulatory spillovers (BIS 2014; Drehmann, Borio, and Tsatsaronis 2011). This is important given that changes in regulation often take place in response to economic and financial conditions while their implementation might, in turn, affect economic outcomes.

\subsection{Stylized Facts}

FACT 1: The degree of internationalization is heterogeneous across German banks. 


\section{Figure 1. Domestic and Foreign Lending Activities of German Banks}
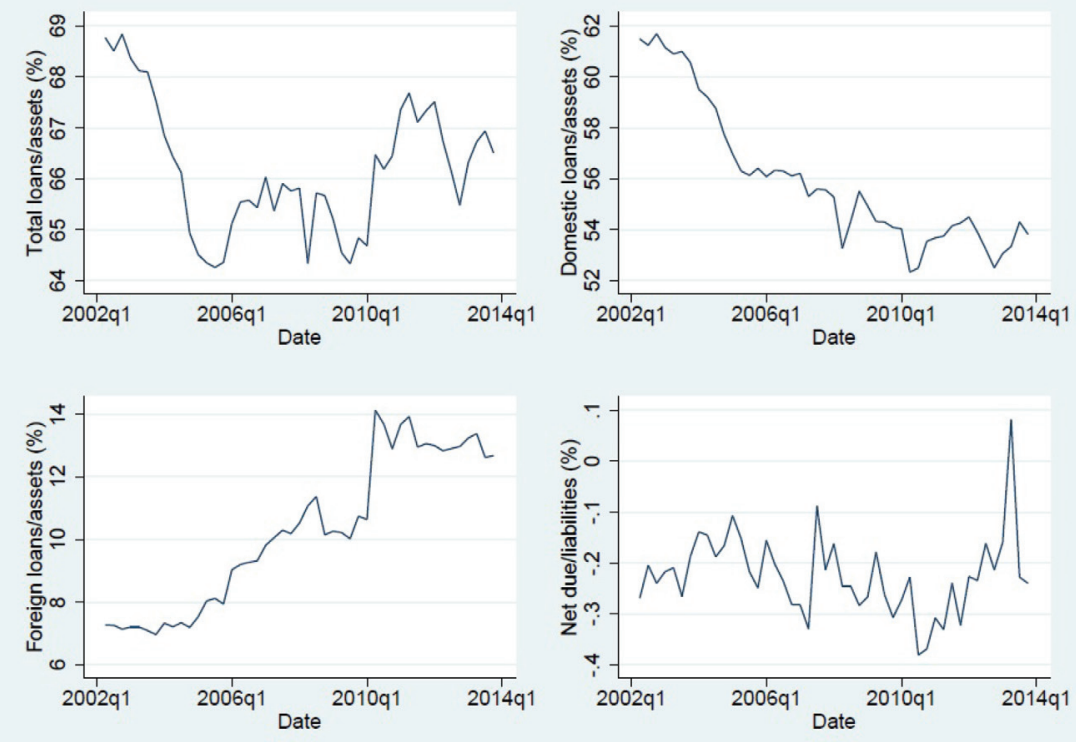

Notes: This figure shows the evolution of German banks' loan supply. Data are observed quarterly from 2002:Q1 to 2013:Q4. The figure shows unweighted averages across the sample of German bank holding companies. Banking data are taken from the monthly balance sheet statistics of Deutsche Bundesbank and are reported at the group level for individual banks. Descriptive statistics are shown for banks' loan-to-asset ratios (in \%), the breakdown into domestic versus foreign loans to assets (in \%), and the net intragroup funding (net due) variable which measures, from the perspective of a bank's headquarters, total net internal borrowing, i.e., liabilities minus claims of the parent bank vis-à-vis all foreign affiliates of the parent bank relative to total liabilities (in \%).

A large percentage of German banks maintain international activities (Buch, Koch, and Koetter 2011b). Figure 1 shows that German banks have recently increased their foreign loan supply relative to assets (lower left graph), whereas this cannot be observed for domestic lending (upper right graph). On average, German banks are net lenders regarding their intragroup positions (lower right graph). Hence, on average, they distribute liquidity to their foreign subsidiaries rather than absorbing liquidity from them. 


\section{Table 3. Correlations between Loan Shares and Balance Sheet Characteristics}

\begin{tabular}{|c|c|c|c|}
\hline \multirow[b]{2}{*}{ Variable } & \multicolumn{3}{|c|}{$\begin{array}{l}\text { All Banks (Inward A) } \\
\quad(\mathrm{N}=3,852)\end{array}$} \\
\hline & $\begin{array}{c}\text { Loans/ } \\
\text { Assets } \\
(\%)\end{array}$ & $\begin{array}{c}\text { Domestic } \\
\text { Loans / } \\
\text { Assets } \\
(\%)\end{array}$ & $\begin{array}{c}\text { Foreign } \\
\text { Loans / } \\
\text { Assets } \\
(\%)\end{array}$ \\
\hline \multicolumn{4}{|c|}{$\begin{array}{l}\text { Correlation with Balance Sheet Variable } \\
\quad(\text { for Each Bank b and Quarter } t)\end{array}$} \\
\hline $\begin{array}{l}\text { Independent Variables: } \\
\text { Total Assets (EUR thousands) } \\
\text { Capital Ratio (\%) } \\
\text { Illiquid Assets Ratio (\%) } \\
\text { International Activity (\%) } \\
\text { Net Intragroup Funding/Liabilities (\%) } \\
\text { Core Deposits Ratio (\%) }\end{array}$ & $\begin{array}{r}-0.24 \\
0.20 \\
0.93 \\
-0.02 \\
-0.09 \\
-0.10\end{array}$ & $\begin{array}{r}-0.38 \\
0.16 \\
0.68 \\
-0.59 \\
0.12 \\
0.14\end{array}$ & $\begin{array}{r}0.31 \\
-0.01 \\
0.06 \\
0.94 \\
-0.31 \\
-0.35\end{array}$ \\
\hline \multicolumn{4}{|c|}{$\begin{array}{l}\text { Notes: This table shows correlations between banks' loan-to-asset ratios and balance } \\
\text { sheet data. Data are observed quarterly from 2002:Q1 to 2013:Q4. Banking data come } \\
\text { from Deutsche Bundesbank's monthly balance sheet statistics and are reported at the } \\
\text { (consolidated) group level. Descriptive statistics are shown for banks' loan-to-asset } \\
\text { ratios (in \%) and the breakdown into domestic versus foreign loans to assets (in \%). } \\
\text { Balance sheet characteristics are as defined in table } 8 \text { in the appendix. }\end{array}$} \\
\hline
\end{tabular}

The size of international activities of German banks and thus presumably their potential to generate cross-border spillovers of regulation varies with the banks' business models: notably, large German banks conduct a relatively large amount of their business abroad (Fiorentino, Koch, and Rudek 2010). Table 3 shows correlations of banks' total, domestic, and foreign loan shares with balance sheet characteristics. Besides the relevance of bank size, it can be seen that German banks' capital and core deposits ratios correlate positively with the share of domestic loans to assets, whereas this finding is less pronounced or even reversed for the share of foreign loans to assets. We will therefore test whether banks' balance sheet characteristics affect their responses to regulatory changes abroad and at home (section 3.1).

Heterogeneity in international activities also comes into play if we look at foreign loans by bank group relative to total foreign 
lending by German banks. For example, in 2013:Q4, around 60 percent of foreign loans granted by German banks can be attributed to the "large commercial banks" and around 20 percent to the "head institutes of savings banks and credit unions," but only 6 percent to "other commercial banks" and less than 1 percent to "savings banks and credit unions." The average bank size in the latter two banking groups is significantly smaller compared with the former two banking groups, such that the result is consistent with the relevance of bank size for the conducting of international activities. Furthermore, comparing large commercial banks and head institutes of savings banks and credit unions with banks in the other banking groups reveals that they have, on average, a lower capital ratio and illiquid assets ratio, they are net lenders regarding their intragroup positions, and they are financed to a lower degree by core deposits. These differences in exposure to foreign activities as well as business models might thus impact the transmission of prudential changes.

FACT 2: Foreign affiliates of German banks include both branches and subsidiaries.

German banks maintain both foreign subsidiaries and foreign branches in a large number of different countries. In an extended analysis on the impact of the organizational structure, we cover around forty destination countries with approximately 170 subsidiaries and 190 aggregates of branches 8 Foreign subsidiaries are assumed to respond differently to foreign regulation than foreign branches. For example, German banks' foreign branches, which are under home-country regulation, can expand/reduce their activities compared with other banks in the foreign country if the latter face a tighter/looser regulatory environment. In section 3.2, we thus analyze whether foreign branches respond differently to a tightening or loosening of foreign policies compared with foreign subsidiaries of German banks.

\footnotetext{
${ }^{8}$ Note that, as described in the data section, we do not have data on individual branches but on the aggregate of branches per German parent bank and foreign country. For example, if the German parent bank A has two branches in the United States, we have information on the sum of these two branches.
} 


\section{Empirical Method and Regression Results}

This section presents the baseline estimations for inward and outward transmission of prudential instruments (section 3.1). We extend our analysis and ask whether banks adjust their lending growth differently depending on their organizational form (section $3.2)$.

\subsection{Baseline Analysis of Inward and Outward Transmission of Prudential Policies}

In the following, we provide a description of the baseline empirical model to study inward and outward transmission and comment on the results. The analysis closely follows the approach described in Buch and Goldberg (2017).

In each specification 1 to 3 , we include our variable of interest, a prudential policy change, both contemporaneously and with its two lags. Furthermore, the prudential policy is interacted with banks' balance sheet characteristics, showing how banks with different (structural) balance sheet characteristics adjust their loan growth in response to changes in regulation. In regression tables 4 to 7 , for the sake of brevity, the reported coefficients are the sum of the contemporaneous term and its two lags, with the corresponding p-values of the F-statistics for joint significance in square brackets. As the prudential instrument enters individually as well as in the interaction effects with bank variables, we calculate a marginal effect (at the average) for both the contemporaneous changes and the sum of contemporaneous and lagged changes. These marginal effects give the effects of regulation for the average bank and are reported at the bottom of each table. Baseline regression models include time and bank fixed effects.

Specification 1: Exposure-weighted inward transmission of regulation (table 4).

$$
\begin{aligned}
\Delta Y_{b, t}= & \alpha_{0}+\left(\alpha_{1} \operatorname{Exp}_{b, t}+\alpha_{2} \operatorname{Exp}_{b, t-1}+\alpha_{3} \operatorname{Exp}_{b, t-2}\right)+\alpha_{4} X_{b, t-1} \\
& +\left(\beta_{1} \operatorname{Exp}_{b, t} \cdot X_{b, t-1}+\beta_{2} \operatorname{Exp}_{b, t-1} \cdot X_{b, t-1}\right. \\
& \left.+\beta_{3} \operatorname{Exp}_{b, t-2} \cdot X_{b, t-1}\right)+f_{b}+f_{t}+\varepsilon_{b, t}
\end{aligned}
$$


where $\Delta Y_{b, t}$ is the log change in the domestic lending of bank $b$ at time $t . X_{b, t-1}$ is a vector of control variables that captures the degree to which a bank is exposed to changes in regulation through ex ante balance sheet composition as described in section 2.1. The prudential policy changes are captured by ExpP, which is an index of exposure-weighted prudential policies outside the home country.

Results for specification 1 are shown in table 4; we see that the exposure-weighted index of changes in the overall prudential index increases domestic lending growth for the average bank (see marginal effects at the bottom of table 4). While this effect is significant contemporaneously, it becomes insignificant in the medium run if we add the effects for the first and second lag to a joint effect. One reason for the lack of medium-run effects can be that most of the changes in instruments are clustered in 2012 and 2013. The result on the prudential index is driven by two instruments: capital requirements and loan-to-value ratios. For the latter, we also see a significant effect for the average bank over current and two lags. In quantitative terms as well, the current effect of the loan-tovalue ratio is strongest: Given a tightening of the policy, loan growth rates increase on average by 15.2 percent, which corresponds to an increase of the median loan growth rate $(0.27$ percent per quarter $)$ by 0.04 percentage points in that quarter. Loan-to-value ratios have been used actively by emerging market economies over our sample period and have been both tightened and loosened. This provides a solid ground for the empirical analysis.

Differences in bank characteristics do not seem to consistently affect the response to regulatory changes abroad. The positive effect in the case of the prudential index is weakened for banks with higher net intragroup positions; banks' response to a tightening in the instrument is more than four times weaker if the net intragroup funding ratio increases by one standard deviation. This might be because foreign affiliates have less scope to provide intragroup funding to the German parent bank given tighter regulation.

SPECIFICATION 2: Inward transmission of home prudential policy via domestic affiliates of foreign global banks (table 5). 


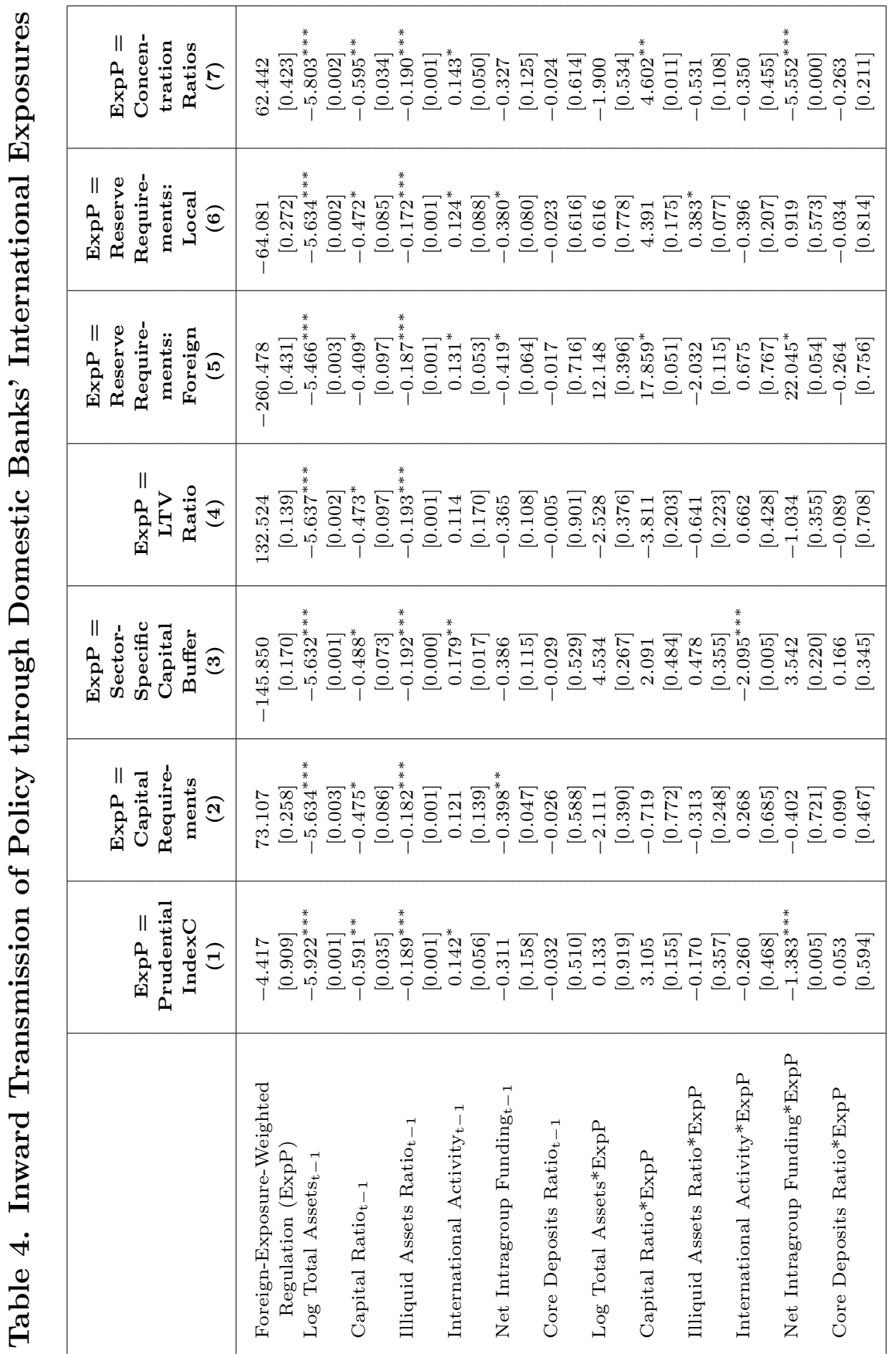




\begin{tabular}{|c|c|c|c|}
\hline 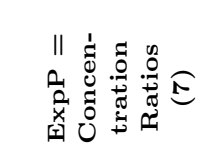 & 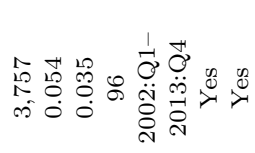 & 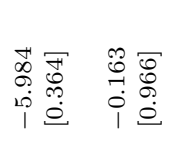 &  \\
\hline 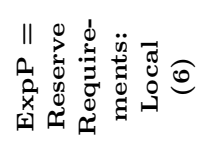 & 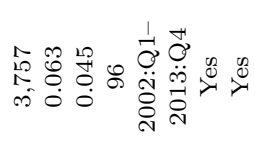 & 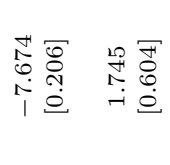 & 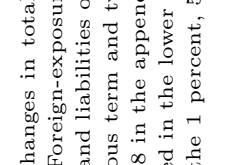 \\
\hline 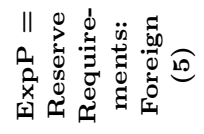 & 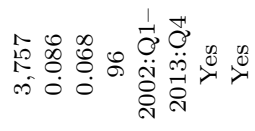 & 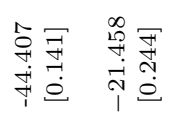 &  \\
\hline 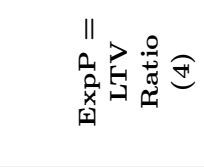 &  & 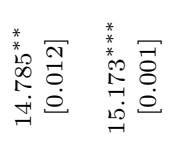 & 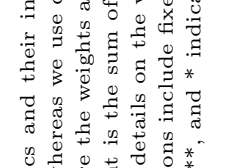 \\
\hline 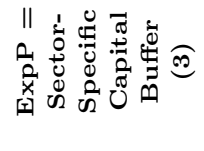 & 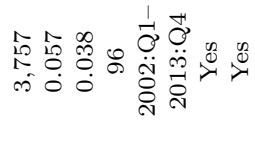 & 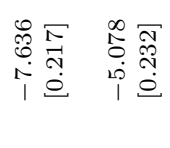 & 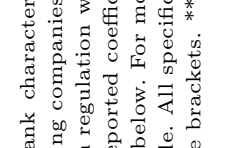 \\
\hline 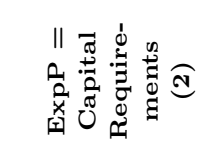 & 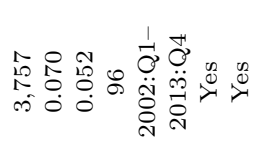 & 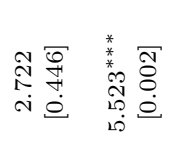 & 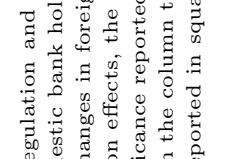 \\
\hline 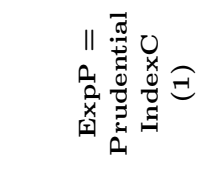 & 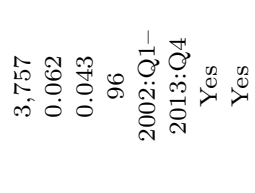 & 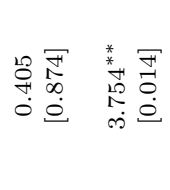 & 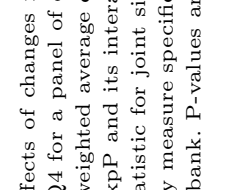 \\
\hline & 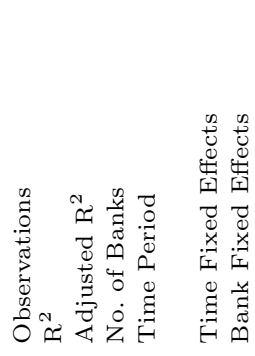 & 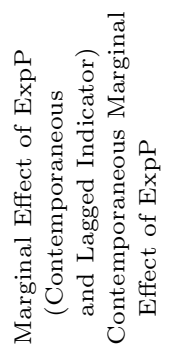 & 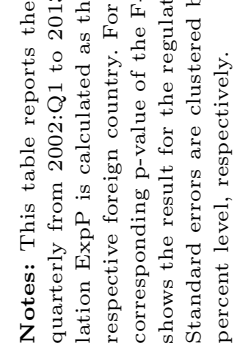 \\
\hline
\end{tabular}




$$
\begin{aligned}
\Delta Y_{b, j, t}= & \alpha_{0}+\left(\alpha_{1} \text {HomeP }_{j, t}+\alpha_{2} \text { HomeP }_{j, t-1}+\alpha_{3} \text {HomeP }_{j, t-2}\right) \\
& +\alpha_{4} X_{b, t-1}+\alpha_{5} Z_{j, t}+\left(\beta_{1} \text {HomeP }_{j, t} \cdot X_{b, t-1}\right. \\
& \left.+\beta_{2} \text {HomeP }_{j, t-1} \cdot X_{b, t-1}+\beta_{3} H_{o m e} P_{j, t-2} \cdot X_{b, t-1}\right) \\
& +f_{b}+f_{t}+\varepsilon_{b, j, t}
\end{aligned}
$$

where $\Delta Y_{b, j, t}$ is the log change in the lending to Germany of an affiliate bank $b$ located in Germany with a foreign parent from country $j$ at time $t 9$ The vector of bank control variables $X_{b, t-1}$ is the same as above. The prudential policy changes are captured by HomeP, reflecting prudential policy in the home country, i.e., the country of the foreign parent bank of the affiliate located in Germany. $Z_{j, t}$ represents the cycle variables for home country $j$.

Results of specification 2 are shown in table 5 . For the average affiliates owned by a foreign global bank (see marginal effects at the bottom of the table), home-country policy is important for sectorspecific capital buffers, loan-to-value ratios, and reserve requirements on local-currency deposits. The latter two instruments have been used mainly by emerging market countries in our sample. An increase in these instruments reduces the host (i.e., German) lending growth by affiliates located in Germany but owned by a foreign parent bank. The economic magnitude of the current effect is strongest for sector-specific capital buffers: Given a tightening of the policy, on average loan growth rates decrease by 17.4 percent, which corresponds to an increase of the median loan growth rate $(1.43$ percent per quarter) by 0.25 percentage point.

This decrease in loan growth can be caused by foreign parents drawing on resources of their affiliates located in Germany to fulfill higher reserve or capital requirements and to maintain lending at home. The effect is, for example, less pronounced for illiquid banks which might have less scope to transfer liquidity to their parent bank. Larger and better-capitalized banks are also affected less severely,

\footnotetext{
${ }^{9}$ Ideally, we would like to distinguish between foreign-owned affiliates that are subject to German (i.e., host-country) regulation and those that are subject to home-country regulation. Unfortunately, our data do not allow us to do so. However, regulatory changes in the home country might be important for both types of foreign affiliates due to the internal capital market and the influence of the parent bank.
} 




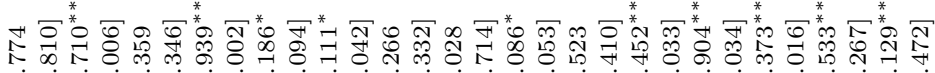

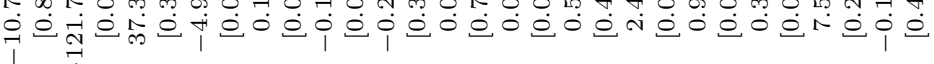

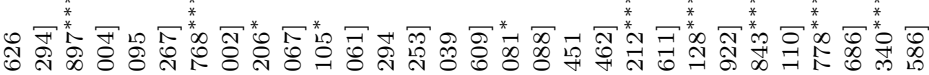

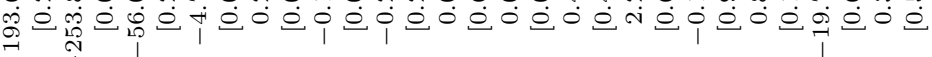



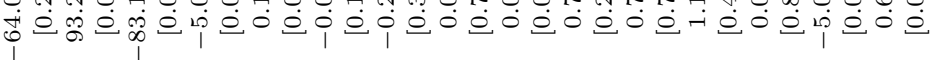

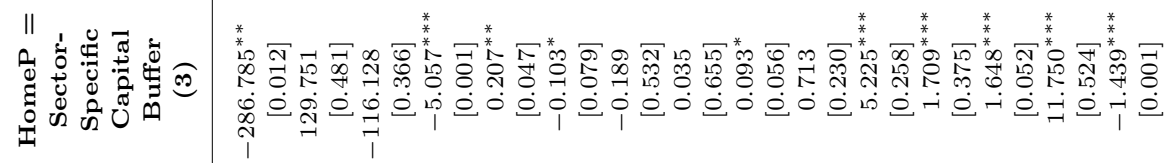

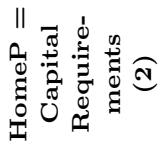

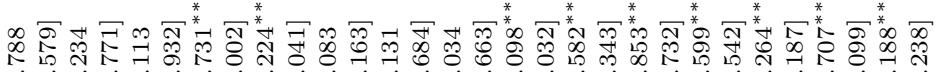

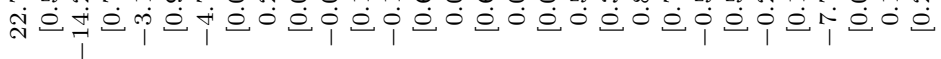

सं

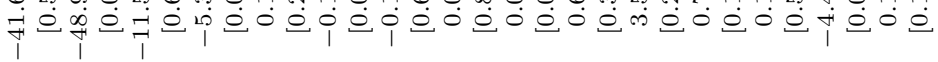

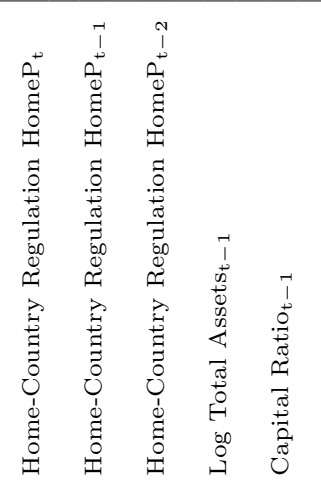

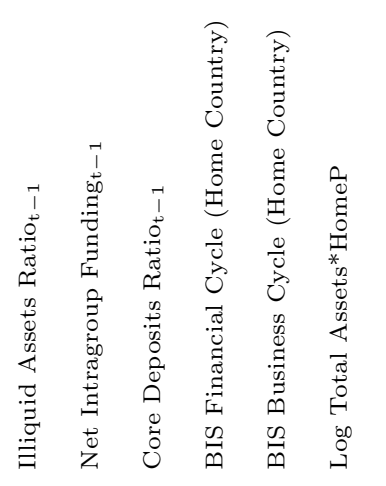

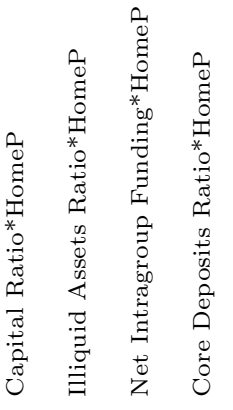




\begin{tabular}{|c|c|c|c|}
\hline 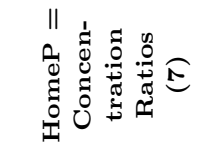 & 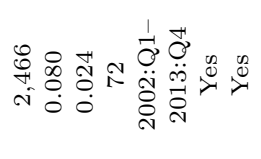 & 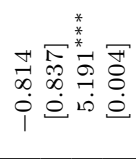 & 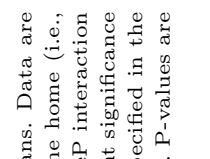 \\
\hline 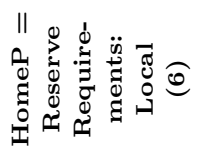 & 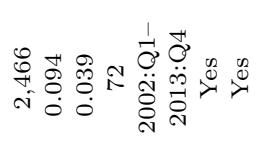 & 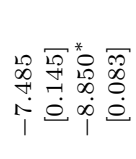 & 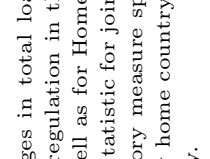 \\
\hline 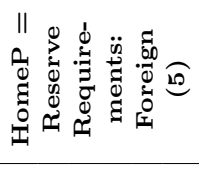 &  & 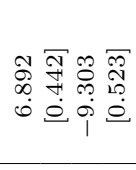 & 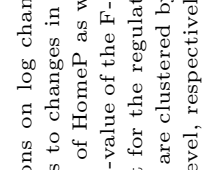 \\
\hline 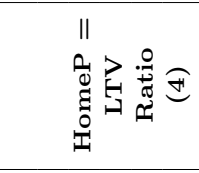 & 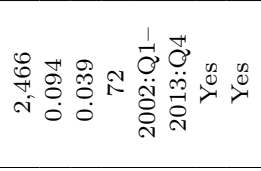 & 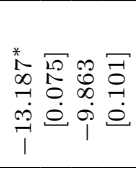 & 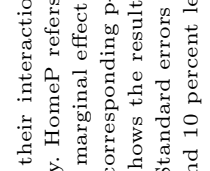 \\
\hline 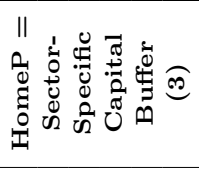 & 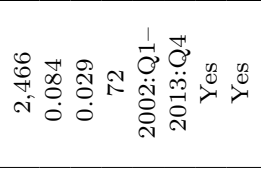 & 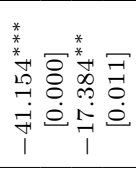 & 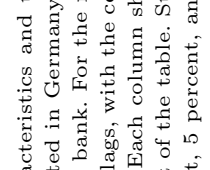 \\
\hline 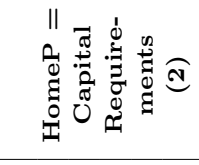 &  & 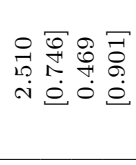 & 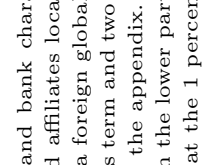 \\
\hline 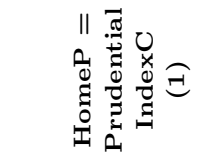 &  & 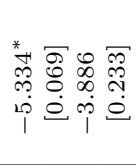 & 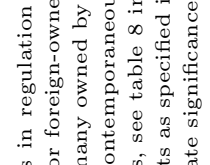 \\
\hline & 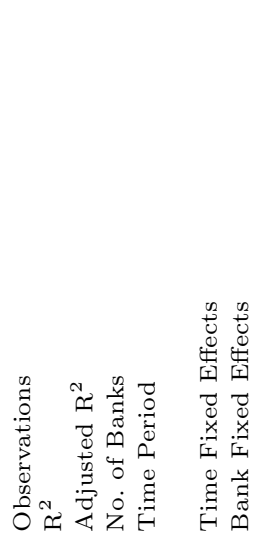 & 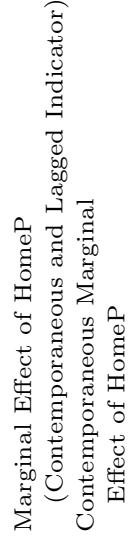 & 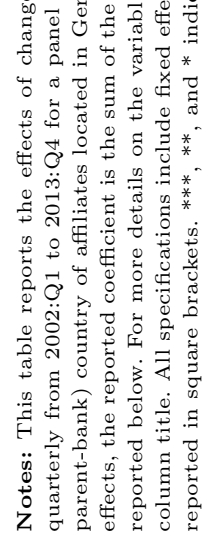 \\
\hline
\end{tabular}


possibly due to higher buffers which allow them to maintain lending growth. Two conclusions can be drawn from these results. First, reductions in lending growth in response to activity-based measures such as loan-to-value ratios might be especially problematic from the perspective of the German regulator if domestic and foreign financial cycles do not coincide. Second, affiliates located in Germany and owned by a foreign parent bank are not independent of homecountry regulation; in particular, tighter regulation in their parent bank's country does not make it more attractive to increase lending growth in Germany 10

Regarding the financial and business cycles, we find that an upswing in the financial cycle of the home country has positive effects on lending growth of affiliates of foreign global banks located in Germany. In sum, this suggests that these affiliates are not independent of developments in the country in which their parent bank is located. Regulatory changes and macroeconomic developments alike are mirrored in their lending activities within the host country.

Specification 3: Outward transmission of destination-country prudential policy (table 6).

$$
\begin{aligned}
\Delta Y_{b, j, t}= & \alpha_{0}+\left(\alpha_{1} \operatorname{Dest}_{j, t}+\alpha_{2} \operatorname{DestP}_{j, t-1}+\alpha_{3} \operatorname{DestP}_{j, t-2}\right) \\
& +\alpha_{4} X_{b, t-1}+\alpha_{5} Z_{j, t}+\left(\beta_{1} \operatorname{DestP}_{j, t} \cdot X_{b, t-1}\right. \\
& \left.+\beta_{2} \operatorname{DestP}_{j, t-1} \cdot X_{b, t-1}+\beta_{3} \operatorname{DestP}_{j, t-2} \cdot X_{b, t-1}\right) \\
& +f_{j}+f_{t}+f_{b}+\varepsilon_{b, j, t}
\end{aligned}
$$

where $\Delta Y_{b, j, t}$ is the log change in the lending of a German global bank $b$ to a foreign destination country $j$ at time $t$. The prudential policy changes are captured by DestP, reflecting prudential changes in the destination country $j$ of the loan by bank $b$. All other variables are defined in parallel to specifications 2 and 3. Again we interpret the effect of the regulatory index by computing its marginal effect for the average bank.

\footnotetext{
${ }^{10}$ Interestingly, a tightening in concentration ratios in the home market has the opposite effect, namely an increase in lending growth to the host (i.e., German) market. With tighter concentration ratios, banks might seek to increase diversification across regions. However, changes in this instrument go back to only two countries (the Netherlands and France), such that these results should be viewed with caution.
} 
Results in table 6 reveal that a tightening in the prudential index of the destination country reduces lending growth of the average German bank to this country. Hence, stricter policies in the destination country spill over to German banks even though these are not always directly subject to the change in regulation. The significant result for the prudential index is driven in particular by changes in reserve requirements. For local reserve requirements, banks not only react in the short run, as can be observed for the prudential index, the concentration ratio, or foreign reserve requirements. The cumulative effect over the current and following two quarters is also negative and significant. Our results thus suggest that reserve requirements which have been used mostly by emerging market countries have indeed been successful in dampening lending inflows 11 A tightening of local reserve requirements relates on average to a short-run decline in loan growth rates by 0.41 percentage point. The negative effect is smaller for banks with more liquid assets, possibly because holding the required reserves may be less costly for these banks but reinforced for banks that obtain higher net intragroup funding.

Finally, macroeconomic developments in the destination country matter for German banks' international loan portfolio. An upturn in the business and financial cycles causes a positive response in loan growth. This suggests that German banks expand across borders during economic and financial upswings in the respective destination country.

\subsubsection{Robustness Tests}

We test the robustness of our results by exploiting the granularity of our data and conducting regressions in which the dependent variable is broken down by loans to banks, the non-bank private sector (i.e., non-financial firms and households), and the public sector. For brevity, we do not report those results that are more explicitly discussed in Ohls, Pramor, and Tonzer (2016). The sector breakdown

\footnotetext{
${ }^{11} \mathrm{An}$ increase in reserve requirements imposes additional costs on funding, which might in turn be passed on to borrowers by increasing loan rates and hence dampening credit growth. To simultaneously reduce the country's attractiveness for foreign capital inflows, an increase in reserve requirements can be accompanied by expansive monetary policy, which translates into lower returns for foreign investors.
} 


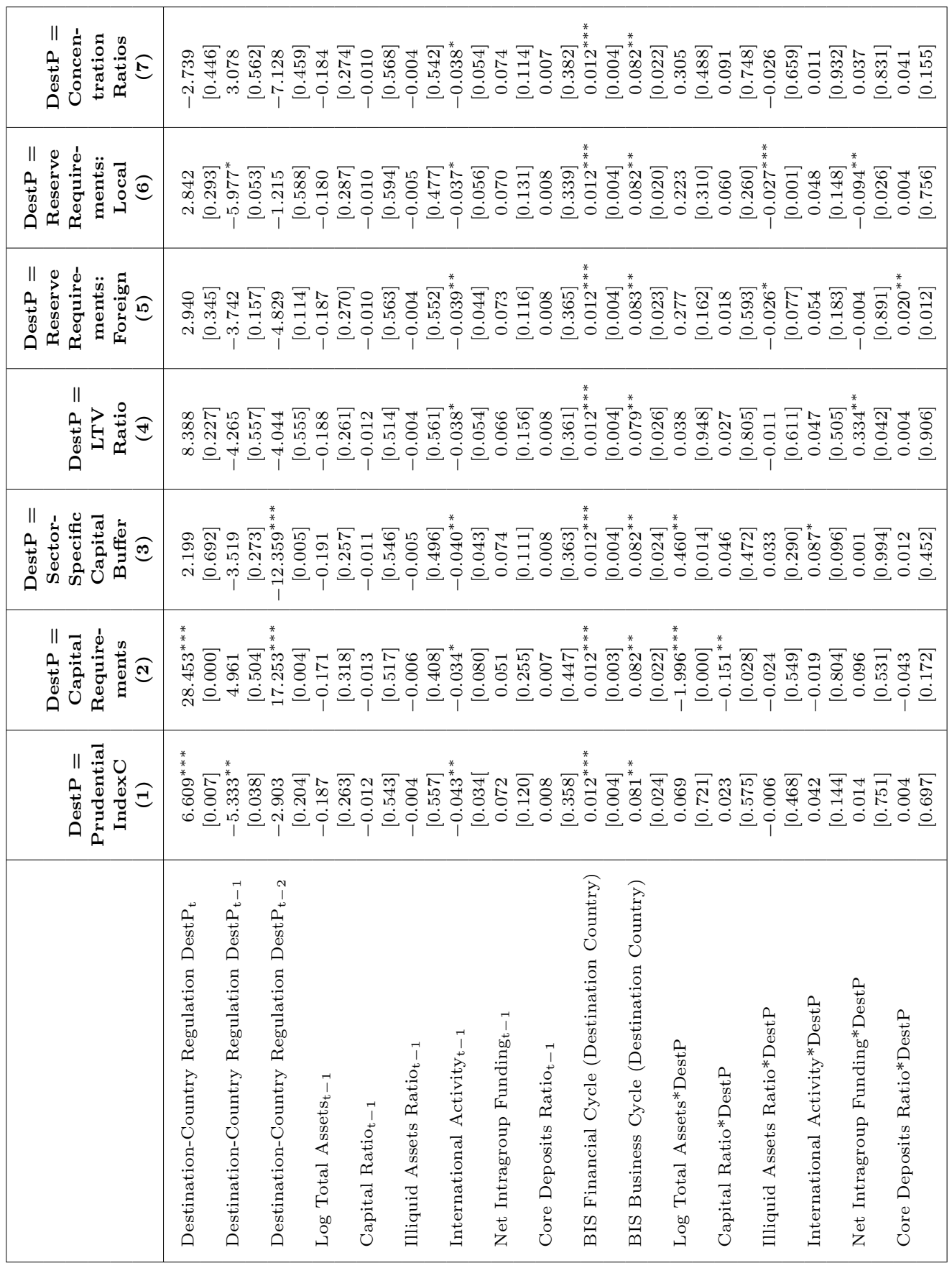




\begin{tabular}{|c|c|c|c|}
\hline 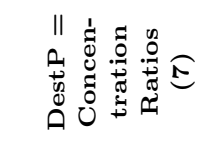 & 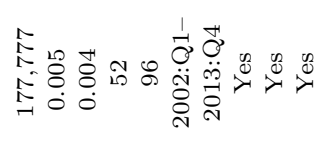 & 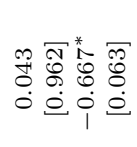 & 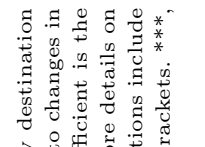 \\
\hline  & 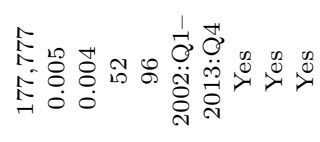 &  &  \\
\hline 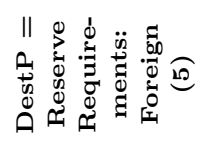 & 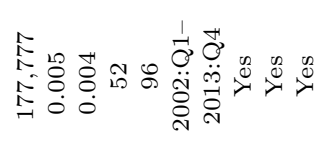 & 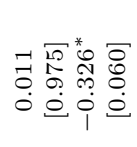 & 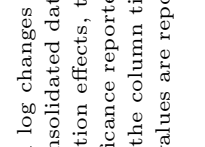 \\
\hline  & 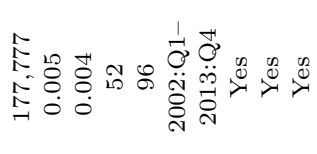 & 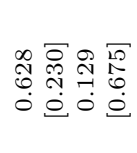 & 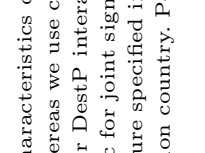 \\
\hline  & 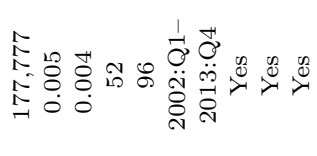 & 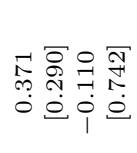 & 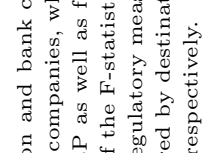 \\
\hline 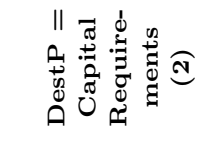 &  & 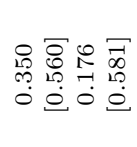 & 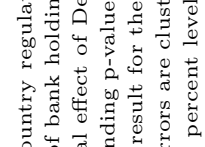 \\
\hline \multirow[t]{2}{*}{ 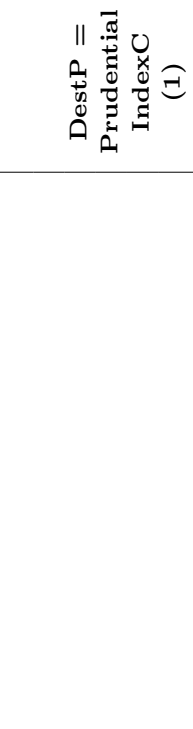 } & 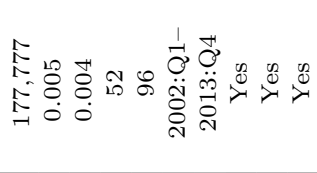 &  & 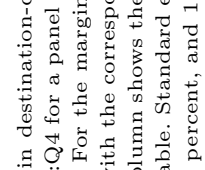 \\
\hline & 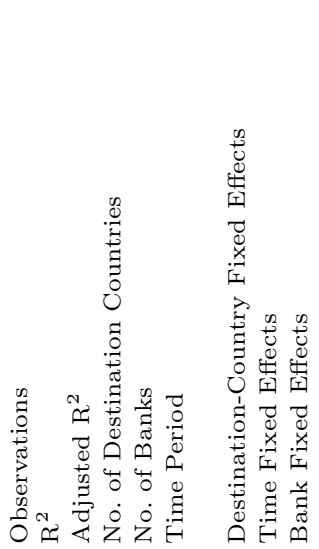 & 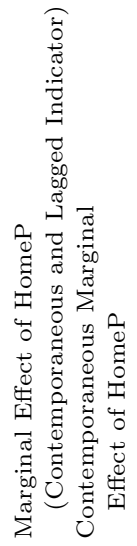 & 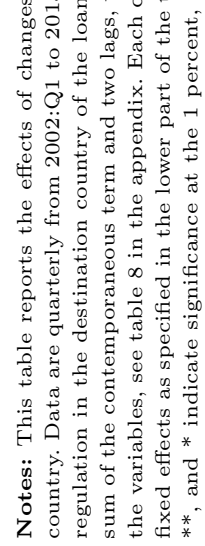 \\
\hline
\end{tabular}


shows that responses to prudential measures vary across loan sectors and specifications, which might explain why we observe only a few significant results for total loan growth. For inward transmission through foreign exposures of domestic global banks, our results are strongest for lending growth to banks and less pronounced to the non-bank private sector. For outward transmission, the negative effect of a tightening in local-currency reserve requirements on German banks' total international lending is confirmed contemporaneously and in the medium run for loan growth toward the non-bank private sector, as well as in the short run toward the bank sector.

We further test the robustness of our results by excluding small exposures of a bank to a foreign country, as this might reflect idiosyncratic business outside the scope of our model. Results remain robust if we exclude the 1 percent or 5 percent smallest destinationcountry bank positions. Finally, we alternate the set of fixed effects, for instance by including country-time fixed effects controlling for demand factors, and clustering the standard errors, which does not cause major changes to our results.

\subsection{Exploration of Organizational Structure}

This section explores whether foreign affiliates of German global banks differ in their lending behavior in response to prudential instruments due to their organizational form. We focus on outward transmission and distinguish between lending by foreign subsidiaries and by foreign branches of German banks. This reduces our sample size relative to table 6, as we exclude all German banks that do not own foreign affiliates but only lend cross-border. Foreign branches and subsidiaries might be affected differently by changes in prudential instruments in the home and the foreign country (Danisewicz, Reinhardt, and Sowerbutts 2015). For institution-based instruments, such as capital requirements or concentration limits, branches tend to be subject to home-country regulation, whereas subsidiaries have to comply with foreign regulation. We use this variation across bank and instrument types to analyze banks' differential responses.

Our approach is similar to specification 3 , but the sample pools across foreign branches and foreign subsidiaries of German banks. We allow for heterogeneous effects of cycle variables, of regulation, and of the interaction between regulation and bank variables by 
interacting them with an indicator variable that equals one in case of a foreign subsidiary. At the bottom of table 7, we report the marginal effects of the prudential instruments for branches and subsidiaries, where the latter consists of the joint effect of the baseline category (=branch) plus the interaction effect. We find that the average foreign subsidiary reduces lending growth contemporaneously following a tightening in the prudential index, sector-specific capital buffers, and loan-to-value ratios. A tightening in foreign reserve requirements leads to a reduction in lending growth of foreign subsidiaries in the medium run. While foreign subsidiaries are thus constrained by foreign regulation, we only find weaker evidence for foreign branches. A tightening in concentration ratios leads to a reduction in lending growth in the short run, while a tightening in the prudential index leads to an increase in lending growth in the medium run (findings significant at the 10 percent level only). Bank characteristics, other than the organizational structure, seem to play a less important role in the response of foreign affiliates to regulatory changes. Overall, we find that foreign subsidiaries react more strongly to foreign regulation. Foreign branches do not generate regulatory leakages by increasing lending growth after a tightening in foreign regulation.

\section{Concluding Remarks}

Global banks may generate cross-border spillovers of the regulatory stance if they adjust their international loan portfolio in response to foreign and domestic regulation. While prudential instruments such as reserve requirements or loan-to-value ratios have mostly been implemented by emerging market countries, in recent times advanced countries have also increased their macroprudential toolkit to target financial stability. For countries like Germany with a highly internationalized banking system, concerns about regulatory spillovers are a topic of utmost importance. Therefore policy discussions and coordination are conducted at the European level at the ESRB. This macroprudential body has recently recommended monitoring cross-border effects of macroprudential instruments on an annual basis (ESRB 2015). Our study may inform this current policy debate by analyzing the inward and outward transmission of regulation for German banks. 







\begin{tabular}{|c|c|c|c|c|c|}
\hline 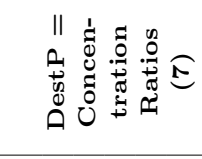 & \multicolumn{2}{|c|}{ 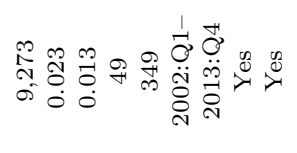 } & 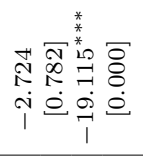 & 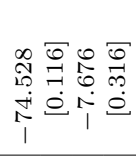 & 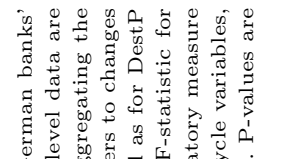 \\
\hline 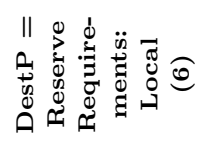 & \multicolumn{2}{|c|}{ 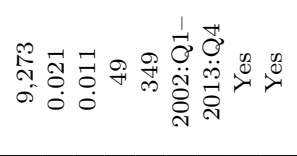 } & 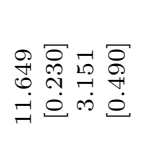 & 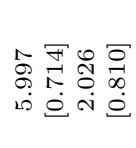 & 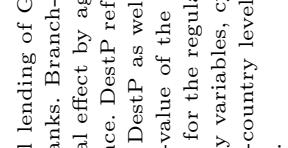 \\
\hline 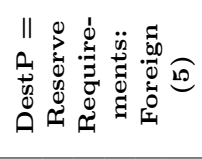 & \multicolumn{2}{|c|}{ 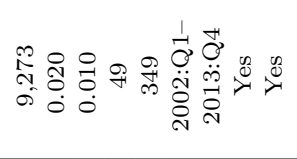 } & 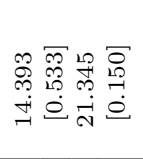 &  & 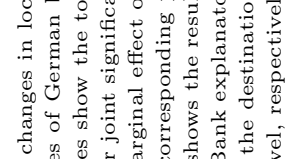 \\
\hline  & \multicolumn{2}{|c|}{ 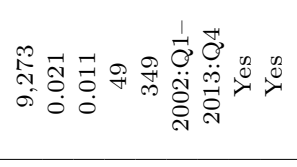 } & 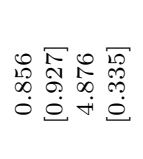 & 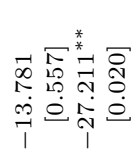 &  \\
\hline 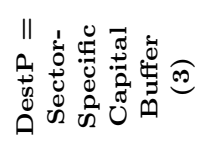 & \multicolumn{2}{|c|}{ 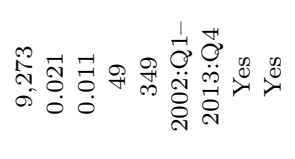 } & 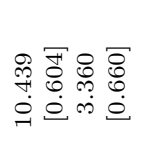 & 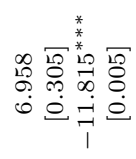 & 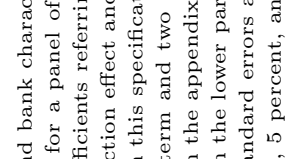 \\
\hline 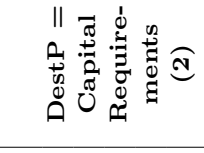 & \multicolumn{2}{|c|}{ 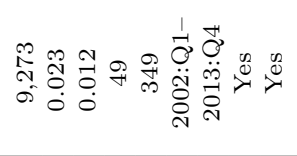 } & 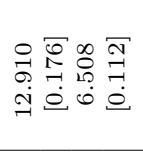 & 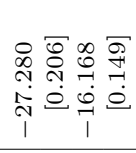 & 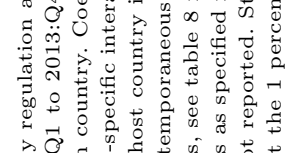 \\
\hline \multirow[t]{2}{*}{ 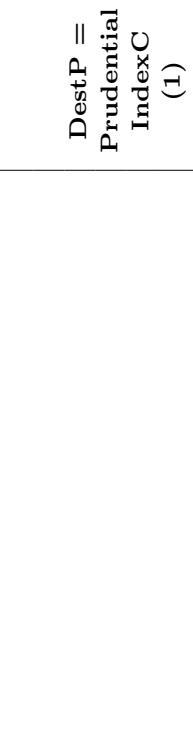 } & \multicolumn{2}{|c|}{ 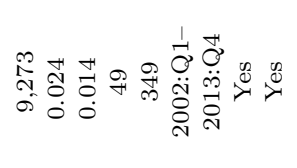 } & 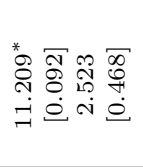 &  &  \\
\hline & 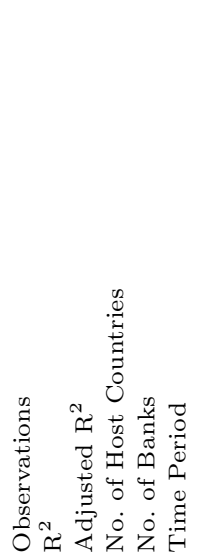 &  & 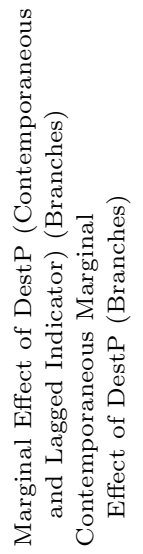 & 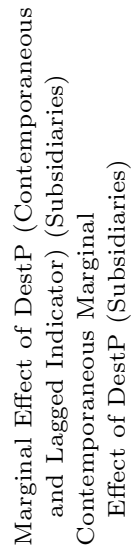 & 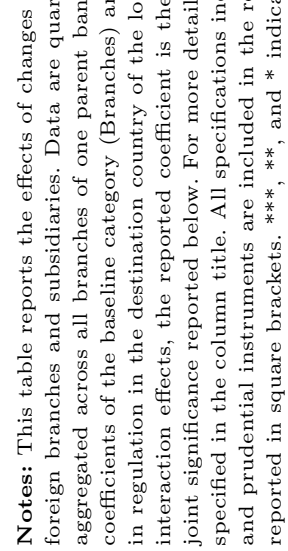 \\
\hline
\end{tabular}


Overall, while we find evidence for cross-border spillovers of regulation, there is no general conclusion that holds true for all types of policy instruments and banks. Instead, heterogeneity between banks, loan types, and specification matters.

Foreign regulatory changes spill over to lending growth in Germany through both domestic affiliates of global foreign banks and German-owned banks which maintain international activities. Affiliates of global foreign banks reduce their local loan growth following a tightening of sector-specific capital buffers, local reserve requirements, and loan-to-value ratios in their parent bank's country. This finding suggests that regulatory pressure can have indirect effects on affiliates owned by global foreign banks if their parent bank draws resources from them in order to fulfill tighter requirements in the home country. German-owned banks also transmit changes in foreign countries' regulatory stance toward German borrowers. A tightening of foreign regulation leads to an increase in domestic lending growth.

Furthermore, we find that German banks reduce foreign lending growth given a tightening in prudential instruments in the destination country. However, these negative responses abate rather quickly, except for reserve requirements. Thus, our results suggest that reserve requirements have been effective in dampening lending inflows by German banks into foreign economies.

Finally, transmission occurs not only because of regulatory changes but also because of economic developments. This is reflected by the fact that business and financial cycles matter for lending decisions: affiliates of foreign global banks increase lending growth in the host country in response to an upturn in the financial cycle of their home country. Also, German banks' international lending behavior is procyclical in the sense that loan growth increases in response to an upturn in the financial and business cycles of the destination country. 


\section{Appendix}

\section{Table 8. Construction of Balance Sheet Independent Variables}

\begin{tabular}{|c|c|c|}
\hline Variable Name & Description & Data Source \\
\hline $\begin{array}{l}\text { Illiquid Assets } \\
\text { Ratio }\end{array}$ & $\begin{array}{l}\text { (Loans and Advances to } \\
\text { Banks + Loans and } \\
\text { Advances to } \\
\text { Non-banks, including } \\
\text { Received Bills)/Assets } \\
\text { (in \%) }\end{array}$ & $\begin{array}{l}\text { Monthly Balance Sheet } \\
\text { Statistics (Deutsche } \\
\text { Bundesbank) }\end{array}$ \\
\hline $\begin{array}{l}\text { Core Deposits } \\
\text { Ratio }\end{array}$ & $\begin{array}{l}\text { Savings Deposits/Assets } \\
\quad \text { (in \%) }\end{array}$ & $\begin{array}{l}\text { Monthly Balance Sheet } \\
\text { Statistics (Deutsche } \\
\text { Bundesbank) }\end{array}$ \\
\hline Capital Ratio & $\begin{array}{l}\text { Equity Capital/Assets } \\
\quad \text { (in \%) }\end{array}$ & $\begin{array}{l}\text { Monthly Balance Sheet } \\
\text { Statistics (Deutsche } \\
\text { Bundesbank) }\end{array}$ \\
\hline $\begin{array}{l}\text { Net Intragroup } \\
\text { Funding }\end{array}$ & $\begin{array}{l}\text { (Liabilities minus Claims } \\
\text { of the Parent Bank } \\
\text { vis-à-vis Foreign } \\
\text { Affiliates, Summed } \\
\text { across All Affiliates per } \\
\text { Parent Bank)/ } \\
\text { Liabilities (in \%) }\end{array}$ & $\begin{array}{l}\text { Monthly Balance Sheet } \\
\text { Statistics (Deutsche } \\
\text { Bundesbank) }\end{array}$ \\
\hline Log Total Assets & $\begin{array}{l}\text { Log (Balance Sheet } \\
\text { Total) }\end{array}$ & $\begin{array}{l}\text { Monthly Balance Sheet } \\
\text { Statistics (Deutsche } \\
\text { Bundesbank) }\end{array}$ \\
\hline $\begin{array}{l}\text { International } \\
\text { Activity Ratio }\end{array}$ & $\begin{array}{l}\text { Ratio of (Foreign Assets } \\
\quad+\text { Foreign Liabilities) } \\
\text { to (Total Assets }+ \\
\text { Total Liabilities) (in \%) }\end{array}$ & $\begin{array}{l}\text { Monthly Balance Sheet } \\
\text { Statistics (Deutsche } \\
\text { Bundesbank) }\end{array}$ \\
\hline
\end{tabular}




\section{References}

Aiyar, S., C. W. Calomiris, and T. Wieladek. 2014. "Does MacroPrudential Regulation Leak? Evidence from a UK Policy Experiment." Journal of Money, Credit and Banking 46 (s1): 181-214.

Bank for International Settlements. 2014. "Debt and the Financial Cycle: Domestic and Global." In 84th Annual Report, 65-84 (chapter IV). Basel, Switzerland: Bank for International Settlements.

Buch, C. M., and L. Goldberg. 2017. "Cross-Border Regulatory Spillovers: How Much? How Important? Evidence from the International Banking Research Network." International Journal of Central Banking 13 (S1).

Buch, C. M., C. T. Koch, and M. Koetter. 2011a. "Crises, Rescues, and Policy Transmission through International Banks." Discussion Paper No. 15/2011, Deutsche Bundesbank.

- 2011b. "Size, Productivity, and International Banking." Journal of International Economics 85 (2): 329-34.

- 2014. "Should I Stay or Should I Go? Bank Productivity and Internationalization Decisions." Journal of Banking and Finance 42: $266-82$.

Buch, C. M., K. Neugebauer, and C. Schröder. 2013. "Changing Forces of Gravity: How the Crisis Affected International Banking." Discussion Paper No. 48/2013, Deutsche Bundesbank.

Cerutti, E., R. Correa, E. Fiorentino, and E. Segalla. 2017. "Changes in Prudential Policy Instruments-A New Cross-Country Database." International Journal of Central Banking 13 (S1).

Claessens, S., S. R. Ghosh, and R. Mihet. 2013. "Macro-Prudential Policies to Mitigate System Vulnerabilities." Journal of International Money and Finance 39: 153-85.

Danisewicz, P., D. Reinhardt, and R. Sowerbutts. 2015. "On a Tight Leash: Does Bank Organisational Structure Matter for Macroprudential Spillovers?" Working Paper No. 524, Bank of England. Drehmann, M., C. Borio, and K. Tsatsaronis. 2011. "Anchoring Countercyclical Capital Buffers: The Role of Credit Aggregates." International Journal of Central Banking 7 (4): 189-240. 
Düwel, C., R. Frey, and A. Lipponer. 2011. "Cross-Border Bank Lending, Risk Aversion and the Financial Crisis." Series 1 Discussion Paper No. 2011/29, Deutsche Bundesbank.

European Systemic Risk Board. 2015. "Recommendation of the European Systemic Risk Board of 15 December 2015 on the Assessment of Cross-Border Effects of and Voluntary Reciprocity for Macroprudential Policy Measures (ESRB/ 2015/2)." Available at https://www.esrb.europa.eu/pub/pdf/ recommendations/2016/Recommendation_ESRB_2015_2.pdf ?b0d610270cb9edc85524d64e7e8a81e7.

Fiorentino E., C. T. Koch, and W. Rudek. 2010. "Microdatabase: External Position Reports of German Banks." Technical Documentation, Deutsche Bundesbank.

Frey, R., and C. Kerl. 2015. "Multinational Banks in the Crisis: Foreign Affiliate Lending as a Mirror of Funding Pressure and Competition on the Internal Capital Market." Journal of Banking and Finance 50: 52-68.

Jiménez, G., S. Ongena, J.-L. Peydro, and J. Saurina Salas. 2012. "Macroprudential Policy, Countercyclical Bank Capital Buffers and Credit Supply: Evidence from the Spanish Dynamic Provisioning Experiments." Discussion Paper No. 2012-011, European Banking Center.

Kerl, C., and C. T. Koch. 2015. "International Banking and Liquidity Risk Transmission: Lessons from Germany." IMF Economic Review 63 (3): 496-514.

Ohls, J., M. Pramor, and L. Tonzer. 2016. "International Banking and Cross-Border Effects of Regulation: Lessons from Germany." Discussion Paper No. 27/2016, Deutsche Bundesbank. 